\title{
Review of the use of cephalosporins in children with anaphylactic reactions from penicillins
}

\author{
Tahir K Hameed MD, Joan L Robinson MD
}

TK Hameed, JL Robinson. Review of the use of cephalosporins in children with anaphylactic reactions from penicillins. Can J Infect Dis 2002;13(4):253-258.

OBJECTIVE: It is a widely accepted practice that children with anaphylaxis from penicillins should avoid cephalosporins. The purpose of the present study was to determine whether there is evidence in the literature to support this practice.

DATA SOURCES: MEDLINE, EMBASE, Toxline, International Pharmaceutical Abstracts and PubMed were used to search the literature published from 1966 to 2001. The Canadian Medical Protective Association, Health Canada and the Boston Collaborative Drug Surveillance Program were also contacted to determine whether there were any unpublished cases of crossreactivity between penicillins and cephalosporins.

DATA EXTRACTION: Cases describing the use of cephalosporins in adults and children with positive penicillin skin tests or anaphylaxis from penicillin were evaluated. Case reports of anaphylaxis from cephalosporins in paediatric patients were identified.

DATA SYNTHESIS: There have been five reported cases of serious reactions from cephalosporins in patients with a history of anaphylaxis from penicillins. All cases occurred in adults; three developed anaphylaxis from the older, first-generation cephalosporins, cephalothin and cephaloridine; one developed anaphylaxis from cefamandole; and one developed anaphylaxis from cefaclor. There have been 12 other published reports of anaphylaxis from cephalosporins in adults with a history of penicillin allergy or a positive penicillin skin test, but with no history of anaphylaxis from penicillin. In seven studies, in which a total of 158 patients with positive penicillin skin tests were administered cephalosporins, seven had apparent immunoglobulin E-mediated reactions when they were given a cephalosporin. When the class of cephalosporin was able to be determined, none of the reports of reactions from cephalosporins in patients with allergies to penicillin involved third-generation cephalosporins. There have been 13 case reports of anaphylaxis from cephalosporins in paediatric patients.

CONCLUSION: There are no published case reports of anaphylaxis from cephalosporins in children with anaphylaxis from penicillin, and there are only a small number of such reports in adults. Anaphylaxis from cephalosporins appears to be incredibly rare in children. There is minimal evidence in the literature to support the avoidance of cephalosporins in children with anaphylaxis from penicillins.

Key Words: Anaphylaxis; Antibiotic allergy; Antibiotic hypersensitivity; Cephalosporins; Cross-reactivity; Drug allergy; Drug hypersensitivity; Penicillin

Résumé à la page suivante

Department of Pediatrics, University of Alberta, Edmonton, Alberta

Correspondence: Dr Joan L Robinson, 2C3 Walter Mackenzie Centre, University of Alberta Hospital, Edmonton, Alberta

T6G 2B6. Telephone 780-407-1680, fax 780-407-7136, e-mail jr3@ualberta.ca

Received for publication June 15, 2001. Accepted February 21, 2002 


\section{Le point sur les céphalosporines chez les enfants ayant des réactions anaphylactiques aux pénicillines}

OBJECTIF : Il est en général accepté dans la pratique d'éviter les céphalosporines chez les enfants qui manifestent des signes d'anaphylaxie avec les pénicillines. Le but de la présente étude est de vérifier si cette pratique s'appuie sur des sources dans la littérature.

SOURCES DES DONNÉES : Les réseaux Medline, Embase, Toxline, International Pharmaceutical Abstracts et PubMed ont été interrogés au sujet des publications parues entre 1966 et 2001. L'Association canadienne de protection médicale, Santé Canada et le Boston Collaborative Drug Surveillance Program ont aussi été contactés afin de déterminer si des cas non publiés de réactivité croisée étaient survenus entre les pénicillines et les céphalosporines.

EXTRACTION DES DONNÉES : Les cas décrivant l'utilisation de céphalosporines chez des adultes et des enfants ayant présenté des résultats positifs aux tests de réaction cutanée à la pénicilline ont été évalués. Les rapports faisant état de réactions anaphylactiques aux céphalosporines chez des enfants ont été recensés.

SYNTHÈSE DES DONNÉES : Cinq cas de réaction grave aux céphalosporines ont été rapportés chez des patients qui avaient des antécédents d'anaphylaxie avec les pénicillines. Tous les cas sont survenus chez des adultes : trois ont développé une anaphylaxie avec les anciennes céphalosporines de première génération, céphalothine et céphaloridine; un a développé une anaphylaxie avec le céphamandole et le dernier avec le céfaclor. Douze autres rapports ont été publiés sur l'anaphylaxie associée aux céphalosporines chez des adultes ayant des antécédents d'allergie à la pénicilline ou un test cutané à la pénicilline positif sans antécédents d'anaphylaxie à la pénicilline. Dans sept études, au cours desquelles en tout 158 patients ayant des tests positifs à la pénicilline ont reçu des céphalosporines, sept sujets ont apparemment présenté des réactions modulées par l'immunoglobuline $\mathrm{E}$ au moment de recevoir leur céphalosporine. Lorsqu'il était possible de déterminer la classe de céphalosporine, aucun des rapports de réaction aux céphalosporines chez les patients allergiques aux pénicillines ne concernait les céphalosporines de $3^{e}$ génération. Treize cas d'anaphylaxie liés aux céphalosporines ont été rapportés chez des enfants.

CONCLUSION : Il n'y a pas de rapports de cas publiés quant à l'anaphylaxie liée aux céphalosporines chez des enfants ayant une anaphylaxie aux pénicillines et seul un petit nombre de rapports ont porté sur des adultes. L'anaphylaxie semble incroyablement rare chez les enfants. Très peu de preuves dans la littérature préconisent d'éviter les céphalosporines chez les enfants allergiques aux pénicillines.

A common problem in paediatrics is determining whether a cephalosporin can be used in a child with a history of a serious reaction from a penicillin, and whether a penicillin can be administered to a child with a history of a serious reaction from a cephalosporin. In many cases, such patients are prescribed antibiotics that are less effective, more toxic, have a broader spectrum or are more expensive than the drug of choice for their condition.

Diagnostic tests for antibiotic allergies are limited and are standardized only for penicillin.

When penicillin is metabolized, the beta-lactam ring opens to form a penicilloyl derivative that, when bound to serum and tissue proteins, accounts for more than $90 \%$ of immunologically active penicillin metabolites (the major determinants). However, about $16 \%$ of allergic reactions to penicillin involve multiple, different antigens that result from further penicillin metabolism. These antigens are referred to as minor determinants (1). In patients who have a history of penicillin allergy but negative skin test results using major and minor determinants, studies have shown that the chance of a serious allergic reaction to penicillin is negligible (1). Skin testing for cephalosporin allergy is sometimes performed, but is not standardized because the antigenic determinants of a serious allergic reaction have not been established.

Standard teaching is that patients who have had possible anaphylaxis from penicillin should be given cephalosporins only with extreme caution, because their risk of developing anaphylaxis from cephalosporins is increased (2). Penicillins have a beta-lactam ring attached to a thialazolidine ring with one side chain, while cephalosporins have a beta-lactam ring attached to a dihydrothiazine ring with two side chains (1) (Figure 1). Because of the similar struc-

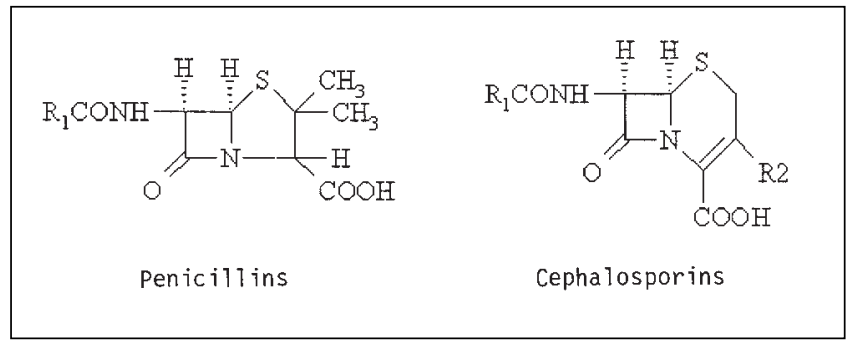

Figure 1) Comparison of chemical structure of penicillins and cephalosporins. $R$ Side chain

tures, there is a theoretical risk of cross-reactivity between penicillins and cephalosporins.

Soon after cephalosporins were introduced, there were reports of anaphylaxis in patients who were given cephalosporins and who had also experienced anaphylaxis from penicillin. Furthermore, during the initial clinical trials with first-generation cephalosporins and cefamandole, $8.1 \%$ of patients with a history of allergy to a penicillin had a possible allergy to a cephalosporin, compared with $4.5 \%$ of patients with no such history (3). However, in those initial trials, no attempt was made to ensure that the reaction to the penicillin or to the cephalosporin was truly allergic. The purpose of the present study was to determine whether there is further evidence in the literature to support the avoidance of cephalosporins in children with suspected penicillin allergies. If the risk of cross-reactivity between penicillins and cephalosporins is low in the adult population, the same is probably true for the paediatric population. Therefore, the incidence of case reports of anaphylaxis from cephalosporins in adults or children with anaphylaxis from penicillin or a positive penicillin skin test was studied. The results of cephalosporin challenge in patients with pos- 
TABLE 1

Summary of case reports of anaphylaxis to cephalosporins in patients with a history of penicillin allergy or a positive penicillin skin test

\begin{tabular}{|c|c|c|c|c|c|c|}
\hline Year, Reference & $\begin{array}{c}\text { Age } \\
\text { (years) }\end{array}$ & Sex & $\begin{array}{l}\text { Reaction to } \\
\text { penicillin }\end{array}$ & $\begin{array}{l}\text { Anaphylaxis } \\
\text { to penicillin } \\
\text { (yes/no) }\end{array}$ & Cephalosporin & $\begin{array}{l}\text { Reaction to } \\
\text { cephalosporin }\end{array}$ \\
\hline$\overline{1965, \text { Kabins et al (4) }}$ & 47 & $\mathrm{~F}$ & $\begin{array}{l}\text { Pruritis and } \\
\text { angioneurotic } \\
\text { edema }\end{array}$ & Yes & Cephalothin & $\begin{array}{l}\text { Hypotensive, wheezing } \\
\text { and unresponsive } \\
\text { within } 2 \text { min }\end{array}$ \\
\hline $\begin{array}{l}\text { 1966, Rothschild and } \\
\text { Doty (23) }\end{array}$ & 56 & M & $\begin{array}{l}\text { Pruritis and } \\
\text { urticaria }\end{array}$ & No & Cephalothin & $\begin{array}{l}\text { Apnea and hypotension } \\
\text { within minutes }\end{array}$ \\
\hline 1966, Drug Letter (24) & 40 & $\mathrm{~F}$ & Rash* $^{*}$ & No & Cephalothin & $\begin{array}{l}\text { Pruritis, dyspnea and } \\
\text { angioneurotic edema }\end{array}$ \\
\hline 1968, Scholand et al (5) & 65 & M & $\begin{array}{l}\text { Urticaria, angio- } \\
\text { neurotic edema } \\
\text { and dyspnea }\end{array}$ & Yes & Cephalothin & $\begin{array}{l}\text { Wheezing and } \\
\text { hypotension within } 30 \mathrm{~s}\end{array}$ \\
\hline 1968, Girard (6) & 1 patient $^{\dagger}$ & & Anaphylaxis* & Yes & Cephaloridine & $\begin{array}{l}\text { Mild anaphylactic } \\
\text { shock }^{*}\end{array}$ \\
\hline 1971, Petz (25) & 2 patients $^{\dagger}$ & & Unknown* & No & Cephalothin & Anaphylaxis* \\
\hline 1974, Spruill et al (10) & 59 & M & Unknown* & Unknown & Cephalothin & Cardiac arrest within $5 \mathrm{~min}$ \\
\hline $\begin{array}{l}\text { 1980, Zeok and } \\
\text { Tsueda (26) }\end{array}$ & 1 patient $^{\dagger}$ & & Urticaria & No & Cephalothin & $\begin{array}{l}\text { Hypotension, bradycardia, } \\
\text { diminished respiratory } \\
\text { excursions and } \\
\text { wheezing, generalized } \\
\text { edema, urticaria }\end{array}$ \\
\hline 1989, Blanca et al (7) & 22 & $\mathrm{~F}$ & $\begin{array}{l}\text { Angioedema of the } \\
\text { mouth and eyes }\end{array}$ & No & Cefamandole & Hypotension \\
\hline 1989, Blanca et al (7) & 50 & $\mathrm{~F}$ & $\begin{array}{l}\text { Hypotension, pruritis } \\
\text { of the lips, breathing } \\
\text { difficulties }\end{array}$ & Yes & Cefamandole & $\begin{array}{l}\text { Hypotension, dysphonia, } \\
\text { generalized pruritis, } \\
\text { and upper airway } \\
\text { obstruction }\end{array}$ \\
\hline 1989, Macnab (27) & 35 & $\mathrm{~F}$ & Unknown* & No & $\begin{array}{l}\text { Cephalexin and } \\
\text { cephalothin }\end{array}$ & $\begin{array}{l}\text { Urticaria, dyspnea, } \\
\text { nausea and severe } \\
\text { headaches }\end{array}$ \\
\hline $\begin{array}{l}\text { 1999, Pumphrey and } \\
\text { Davis (8) }\end{array}$ & 76 & $\mathrm{~F}$ & $\begin{array}{l}\text { Anaphylaxis to } \\
\text { amoxicillin* }\end{array}$ & Yes & Cefaclor & Fatal anaphylaxis* \\
\hline $\begin{array}{l}\text { 1999, Pumphrey and } \\
\text { Davis (8) }\end{array}$ & 3 patients $^{\dagger}$ & & $\begin{array}{l}\text { Two allergic to } \\
\text { amoxicillin } \\
\text { and } 1 \text { allergic to } \\
\text { penicillin* }\end{array}$ & Unknown & Unknown & Fatal anaphylaxis* \\
\hline 1999, Nordt et al (28) & 32 & $\mathrm{~F}$ & Unknown* & Unknown & Cephalexin & $\begin{array}{l}\text { Rapid onset of throat } \\
\text { tightness and urticaria }\end{array}$ \\
\hline
\end{tabular}

${ }^{*}$ No further details of the reactions were given; ${ }^{\dagger}$ Ages unknown. F Female; M Male

itive penicillin skin tests were also reviewed. If it is exceedingly rare for children to develop anaphylaxis from cephalosporins, it may not be necessary to avoid their use in children who are allergic to penicillins. Therefore, the total number of published case reports of anaphylaxis from cephalosporins in all children was also researched.

\section{DATA AND METHODS}

The literature was reviewed for results of cephalosporin challenge in adults or children with anaphylactic reactions from penicillin or with positive penicillin skin tests. Case reports of anaphylaxis from cephalosporins in paediatric patients (up to 16 years of age) were also researched. MEDLINE, EMBASE, Toxline, International Pharmaceutical
Abstracts and PubMed were used to search the literature published from 1966 to 2001, using 'anaphylaxis', 'penicillin', 'cephalosporin', 'beta-lactams', 'cross-reactivity', 'cross-sensitivity', 'drug allergy' and 'drug hypersensitivity' as keywords, and by referencing the bibliographies of related papers. Cases with urticaria or life-threatening symptoms (apnea, bronchospasm or hypotension) were considered to be anaphylaxis. We also contacted Health Canada, the Canadian Medical Protective Association (CMPA) and the Boston Collaborative Drug Surveillance Program to determine whether they were aware of any unpublished cases of cross-reactivity between penicillins and cephalosporins, and anaphylaxis from cephalosporins in children. 
TABLE 2

Summary of studies of cephalosporin challenge in patients with positive skin tests for allergies to penicillin

\begin{tabular}{|c|c|c|c|c|c|}
\hline Reference (year) & $\begin{array}{l}\text { Patients } \\
\text { challenged with } \\
\text { cephalosporins }\end{array}$ & $\begin{array}{l}\text { Patients with } \\
\text { negative } \\
\text { challenge }\end{array}$ & $\begin{array}{l}\text { Patients with } \\
\text { positive } \\
\text { challenge }\end{array}$ & Cephalosporin & $\begin{array}{l}\text { Reaction if } \\
\text { positive } \\
\text { challenge }\end{array}$ \\
\hline $\begin{array}{l}\text { Assem and Vickers } \\
\text { (29) (1974) }\end{array}$ & $2^{*}$ & 0 & $2^{*}$ & Cephaloridine & $\begin{array}{l}\text { Anaphylactic reaction }{ }^{\dagger} \text { in } \\
\text { first patient, extensive } \\
\text { urticaria in second patient }\end{array}$ \\
\hline $\begin{array}{l}\text { Warrington et al } \\
\text { (30) (1978) }\end{array}$ & 3 & 3 & 0 & Not applicable & Not applicable \\
\hline $\begin{array}{l}\text { Solley (31) } \\
(1982)\end{array}$ & 27 & 27 & 0 & Not applicable & Not applicable \\
\hline Rohr (32) (1987) & 62 & 61 & 1 & Not specified & $\begin{array}{l}\text { Mild urticaria and bron- } \\
\text { chospasm }^{\dagger}\end{array}$ \\
\hline Blanca et al (7) (1989) & $12^{\ddagger}$ & 10 & 2 & Cefamandole & $\begin{array}{l}\text { In one patient, profound and } \\
\text { sustained hypotension; in } \\
\text { the other patient, transient } \\
\text { hypotension, dysphonia, } \\
\text { generalized pruritus, and } \\
\text { upper airway breathing } \\
\text { difficulties }\end{array}$ \\
\hline $\begin{array}{l}\text { Shepherd and } \\
\text { Burton (33) (1993) }\end{array}$ & 9 & 9 & 0 & Not applicable & Not applicable \\
\hline $\begin{array}{l}\text { Pichichero and } \\
\text { Pinchichero (9) (1988) }\end{array}$ & $43^{\S}$ & 41 & 2 & Not specified & $\begin{array}{l}\text { Mild IgE-mediated } \\
\text { reactions }^{\dagger}\end{array}$ \\
\hline
\end{tabular}

${ }^{*}$ Although three patients had positive challenges with cephalosporins, only two patients had suspected lgE-mediated reactions; ${ }^{\dagger}$ No further details were provided; ¥Three penicillin skin-test-negative patients were selected on the basis of positive penicillin challenge; $\$$ Treatment courses with cephalosporins. IgE Immunoglobulin E

\section{RESULTS}

A review of case reports of anaphylaxis from cephalosporins in adults or children with a history of penicillin allergy or a positive penicillin skin test is presented in Table 1. In five cases (4-8), patients with a history of anaphylaxis from penicillin developed anaphylaxis from a cephalosporin. Three of the cases involved anaphylaxis from the older, first-generation cephalosporins, cephalothin and cephaloridine, while two cases involved anaphylaxis from the second-generation cephalosporins, cefaclor and cefamandole. There were 12 other published reports of anaphylaxis from cephalosporins in adults with a history of penicillin allergy or a positive penicillin skin test but with no history of anaphylaxis from penicillin. In nine of these cases, the class of cephalosporin was known (six were cephalothin, one was both cephalothin and cephalexin, one was cephalexin and one was cefamandole). The CMPA was not aware of any legal action in Canada that resulted from the administration of a cephalosporin to a patient with an allergy to penicillin. Health Canada's Adverse Drug Reaction Monitoring Program and the Boston Collaborative Drug Surveillance Program had no additional unpublished reports of anaphylaxis from cephalosporins in patients who were allergic to penicillin.

Table 2 summarizes the studies of cephalosporin challenge in children and adults with positive penicillin skin tests. Only one study (9) focused on paediatric patients. Of a total of 158 patients, there were seven positive challenges with cephalosporins. Four of the seven suspected immunoglobulin E ( $\mathrm{IgE}$ )-mediated reactions were mild (one reaction to cephaloridine and three reactions in which the cephalosporin was not specified), while three were serious reactions that consisted of anaphylaxis from cephaloridine or cefamandole.

There were 13 reported cases of anaphylaxis from cephalosporins in children (Table 3). One case involved the old, first-generation cephalosporin cephalothin (10), four cases involved second-generation cephalosporins (cefaclor, cefamandole, cefotetan and cefuroxime) (11-13) and eight cases involved a third-generation cephalosporin (ceftriaxone in seven patients and ceftazidime in one patient) (14-16).

\section{DISCUSSION}

There have been only 17 published case reports of anaphylaxis from cephalosporins in patients with a history of penicillin allergy or a positive penicillin skin test. All cases occurred in adults. In nine of the 14 cases in which the class of cephalosporin could be determined, anaphylaxis was from first-generation cephalosporins, while the other five cases were anaphylaxis from second-generation cephalosporins. However, one limitation of the present study was that the reporting of cases was sporadic. Therefore, the infrequency of case reports may have been due to the fact that physicians 
TABLE 3

Case reports of anaphylaxis from cephalosporins in children

\begin{tabular}{|c|c|c|c|c|}
\hline Reference & Age (years) & Sex & Cephalosporin & Reaction to cephalosporin \\
\hline Romano et al (14) (1999) & 15 & Male & Ceftriaxone & $\begin{array}{l}\text { Urticaria, dyspnea, tachycardia and } \\
\text { severe hypotension within } 5 \text { min }\end{array}$ \\
\hline Grouhi et al (11) (1999) & 2 & Male & Cefaclor & $\begin{array}{l}\text { Vomiting, generalized hives, shortness } \\
\text { of breath, wheezing with grunting and } \\
\text { loss of consciousness }\end{array}$ \\
\hline Wessel (12) (1998) & 6 & Female & Cefamandole & Anaphylactic shock* \\
\hline Spruill et al (10) (1974) & 11 & Male & Cephalothin & Hypotension and shock \\
\hline \multirow[t]{6}{*}{ Romano et al (15) (2000) } & 6 & Male & Ceftriaxone & Urticaria \\
\hline & 7 & Female & Ceftriaxone & Anaphylactic shock* \\
\hline & 14 & Male & Ceftriaxone & Anaphylactic shock ${ }^{*}$ \\
\hline & 12 & Female & Ceftriaxone & Anaphylactic shock ${ }^{*}$ \\
\hline & 5 & Female & Ceftriaxone & Anaphylactic shock* \\
\hline & 9 & Female & Ceftriaxone & Anaphylactic shock* \\
\hline Romano et al (16) (2001) & 16 & Female & Ceftazidime & $\begin{array}{l}\text { Anaphylactic shock (urticaria, rhinitis, } \\
\text { wheezing, dyspnea and hypotension) }\end{array}$ \\
\hline Health Canada (13) (2001) & 10 & Female & Cefotetan & $\begin{array}{l}\text { Flushing, hypotension, atrial arrhythmia and } \\
\text { tachycardia }\end{array}$ \\
\hline Health Canada (13) (2001) & 8 & Female & Cefuroxime & Urticaria and edema \\
\hline
\end{tabular}

*No further details were provided

are very compliant about not prescribing cephalosporins to patients with suspected penicillin allergies, the cases of cross-reactivity between penicillins and cephalosporins that occur are often not reported, or that it is very rare for crossreactivity to occur.

There have been seven studies in which 158 patients with positive penicillin skin tests were administered cephalosporins; seven had IgE-mediated reactions when they were administered a cephalosporin. Four of the reactions were mild (one reaction was to cephaloridine and three were in reaction to a cephalosporin that was not specified). There was one serious reaction to cephaloridine and two serious reactions to cefamandole in patients with allergies to penicillin. A possible explanation for the three serious reactions is that of all the cephalosporins, cephaloridine and cefamandole have side chain structures that are most similar to penicillin and, thus, cross-reactivity may have occurred (2).

When the class of the cephalosporin was specified, none of the serious reactions to cephalosporins in patients with positive penicillin skin tests involved third-generation cephalosporins. The risk of serious allergic reactions from cephalosporins in the general population appears to be less than $0.02 \%$, and the risk is lowest for third-generation cephalosporins (possibly because cephalosporins are thought to be only antigenic if the side chain is bound to a serum protein, and free side chains compete with bound side chains for binding to IgE antibodies) $(17,18)$.

Anaphylaxis from cephalosporins appears to be incredibly rare in children, with only 13 case reports in the literature. However, it is likely that not all cases would have been reported or even recognized. It is interesting that eight of those case reports came from Romano $(15,16)$. He also mentioned a six-year-old with an immediate reaction to a cephalosporin in another paper (19), but it is not clear if this was an additional case. A recent review article found only 54 published cases of anaphylaxis to cephalosporins in both adults and children, but did not include all of the paediatric cases found in the present study $(12,15,16)$.

The reason why a high incidence of cross-reactivity between penicillins and cephalosporins was thought to be likely is that both have a beta-lactam ring. However, there is increasing evidence that, in most allergic reactions to cephalosporins, it is the side chain rather than the beta-lactam ring that is the antigen (2). It is only the older, firstand second-generation cephalosporins (cephalothin, cephaloridine and cefamandole) that have a side chain that is similar to that of penicillin, while cephalexin has a side chain that is identical to that of ampicillin. In addition, older, first-generation cephalosporins were sometimes contaminated with penicillin before 1980 (20). These two facts may account for some of the early reports of cross-reactivity between penicillins and cephalosporins. Furthermore, the results of penicillin skin testing are not predictive of cephalosporin allergy, which again suggests that there is limited cross-reactivity (3).

There is evidence that patients with a history of penicillin allergy have three times the rate of patients in control groups of having an allergic reaction to any other antibiotic (17). Therefore, even if the risk of patients with a history of penicillin allergy having a serious reaction to cephalosporins is double that of patients in control groups, 
this risk may be lower than the risk of them having a serious reaction to any alternative antibiotic (2). It has been suggested that the low incidence of serious allergic reactions to cephalosporins may relate to the lack of stability of immunogenic metabolites (16).

\section{CONCLUSIONS}

There is minimal evidence in the literature to support the avoidance of cephalosporins in children with anaphylaxis from penicillins. Despite published guidelines to the contrary (20), a child or adult with a previous mild reaction to a peni-

\section{REFERENCES}

1. Sogn DD, Evans R, Shepherd GM, et al. Results of the National Institute of Allergy and Infectious Diseases collaborative clinical trial to test the predictive value of skin testing with major and minor penicillin derivatives in hospitalized adults. Arch Intern Med 1992;152:1025-32.

2. Weiss ME, Adkinson NF. Beta-lactam allergy. In: Mandell GL, Bennett JE, Dolin R, eds. Principles and Practice of Infectious Diseases, 5th edition. Philadelphia: Churchill Livingstone, 2000:299-305

3. Kim S, Warrington RJ. Clinical cross-reactivity between penicillins and cephalosporins. Can J Allergy Clin Immunol 1998;3:12-5.

4. Kabins SA, Eisenstein B, Cohen S. Anaphylactoid reaction to an initial dose of sodium cephalothin. JAMA 1965;193:165-6.

5. Scholand JF, Tennenbaum JI, Cerilli GJ. Anaphylaxis to cephalothin in a patient allergic to penicillin. JAMA 1968;206:130-2.

6. Girard JP. Common antigenic determinants of penicillin G, ampicillin and the cephalosporins demonstrated in men. Int Arch Allergy 1968;33:428-38.

7. Blanca M, Fernandez J, Miranda A, et al. Cross-reactivity between penicillins and cephalosporins: Clinical and immunologic studies. J Allergy Clin Immunol 1989;83:381-5.

8. Pumphrey RSH, Davis D. Under-reporting of antibiotic anaphylaxis may put patients at risk. Lancet 1999;353:1157-8.

9. Pichichero ME, Pichichero DM. Diagnosis of penicillin, amoxicillin, and cephalosporin allergy: Reliability of examination assessed by skin testing and oral challenge. J Pediatr 1998;132:137-43.

10. Spruill FG, Minette LJ, Sturner WQ. Two surgical deaths associated with cephalothin. JAMA 1974;229:440-1.

11. Grouhi M, Hummel D, Roifman CM. Anaphylactic reaction to oral cefaclor in a child. Pediatrics 1999;103:50.

12. Wessel F. Les allergies per-anesthetiques aux antibiotiques. Allergie et Immunologie 1998;30:190-2.

13. Canadian Adverse Drug Reaction Monitoring Program. Summary of Reported Adverse Drug Reactions. Ottawa: Health Canada, 2001.

14. Romano A, Quaratino D, Venemalm L, Torres MJ, Venuti A, Blanca M. A case of IgE-mediated hypersensitivity to ceftriaxone. J Allergy Clin Immunol 1999;104:1113-4.

15. Romano A, Mayorga C, Torres MJ, et al. Immediate allergic reactions to cephalosporins: Cross-reactivity and selective responses. J Allergy Clin Immunol 2000;106:1177-83.

16. Romano A, Di Fonso M, Artesani MC, Viola M, Adesi FB, Venuti A. Selective immediate hypersensitivity to ceftazidime. Allergy 2001;56:84-5. cillin can probably safely be administered a cephalosporin. If a more serious reaction to a penicillin has occurred, yet the patient has a negative penicillin skin test, it is probably safe to administer a cephalosporin (21). However, if skin testing cannot be done or if a patient is known to have had a positive penicillin skin test, it is not advisable to administer a full dose of an intravenous cephalosporin in the face of standard recommendations against this practice (20). However, it would appear to be safe to administer a supervised, graded challenge with a nonfirst-generation cephalosporin other than cefamandole or to embark on desensitization (22).
17. Anne S, Reisman RE. Risk of administering cephalosporin antibiotics to patients with histories of penicillin allergy. Ann Allergy Asthma Immunol 1995;74:167-70.

18. Adkinson NF. Drug allergy. In: Middleton E, Reed CE, Ellis EF, et al, eds. Allergy - Principals and Practice, 5th edn. St Louis: Mosby, 1998:1214-24.

19. Romano A, Quaratino I, Aimone-Gastin I, et al. Cephalosporin allergy: Characterization of unique and cross-reacting cephalosporin antigens. Int J Immunopathol Pharmacol 1997;10:187-91.

20. Joint Task Force on Practice Parameters; American Academy of Allergy, Asthma and Immunology, Joint Council of Asthma, Allergy and Immunology. Executive summary of disease management of drug hypersensitivity: A practice parameter. Ann Allergy Asthma Immunol 1999;83:665-700.

21. Kelkar PS, Li JT. Cephalosporin allergy. N Engl J Med 2001;345:804-9.

22. Mendelson LM. Adverse reactions to beta-lactam antibiotics. Immunol Allergy Clin North Am 1998;18:745-57.

23. Rothschild PD, Doty DB. Cephalothin reaction after penicillin sensitization. JAMA 1966;196:372-3.

24. Drug letter II. Report of a drug reaction: Allergic reaction to cephalothin in a patient with penicillin hypersensitivity. Bull Johns Hopkins Hosp 1966;118:352-3.

25. Petz LD. Immunologic reactions of humans to cephalosporins. Postgrad Med J 1971;47:(Suppl):64-9.

26. Zeok SS, Tsueda K. Failure of a cephalothin test dose to produce anaphylaxis. Anesth Analg 1980;59:393-4.

27. Macnab KA. Cross allergenicity of penicillins and cephalosporins. Can J Hosp Pharm 1989;42:81-4.

28. Nordt SP, Cantrell FL, Rodriguez GJ. Anaphylactic reaction to dermal exposure to cephalexin. Am J Emerg Med 1999;17:492-3.

29. Assem ES, Vickers MR. Tests for penicillin allergy in man. II. The immunological cross-reaction between penicillins and cephalosporins. Immunology 1974;27:255-69.

30. Warrington RJ, Simons FER, Ho HW, Gorski BA. Diagnosis of penicillin allergy by skin testing: The Manitoba experience. CMAJ 1978;118:787-91.

31. Solly GO, Gleich GJ, Van Dellen RG. Penicillin allergy: Clinical experience with a battery of skin-test reagents. J Allergy Clin Immunol 1982;69:238-44.

32. Rohr AS. Cephalosporins. In: Saxon A, moderator. Immediate hypersensitivity reactions to beta-lactam antibiotics. Ann Intern Med 1987;107:210

33. Shepherd GM, Burton DA. Administration of cephalosporin antibiotics to patients with a history of penicillin allergy. J Allergy Clin Immunol 1993;91:262. (Abst) 


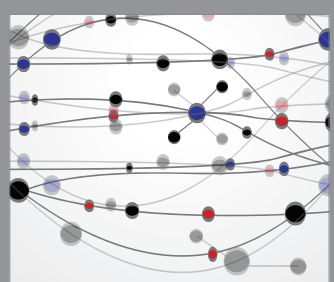

The Scientific World Journal
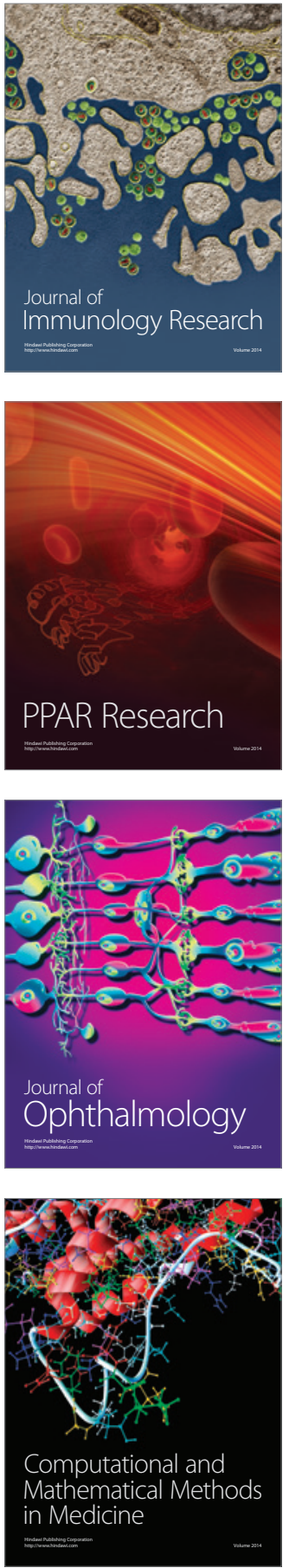

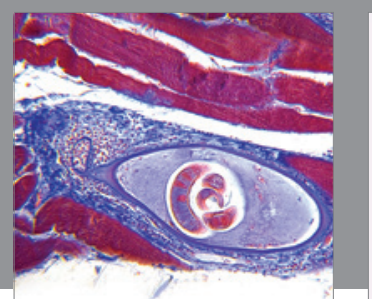

Gastroenterology Research and Practice

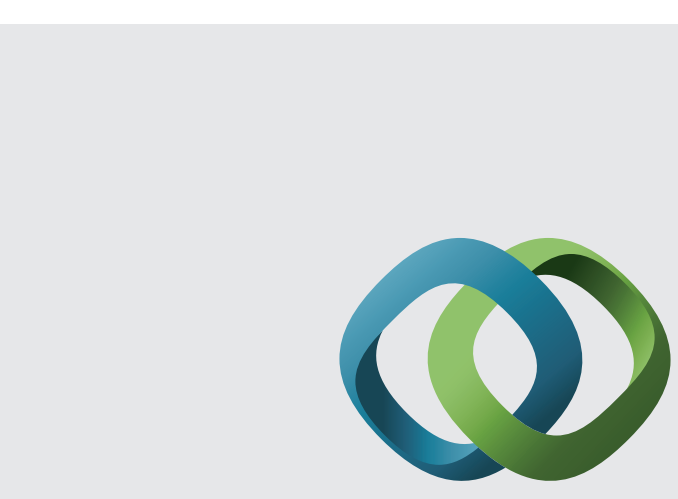

\section{Hindawi}

Submit your manuscripts at

http://www.hindawi.com
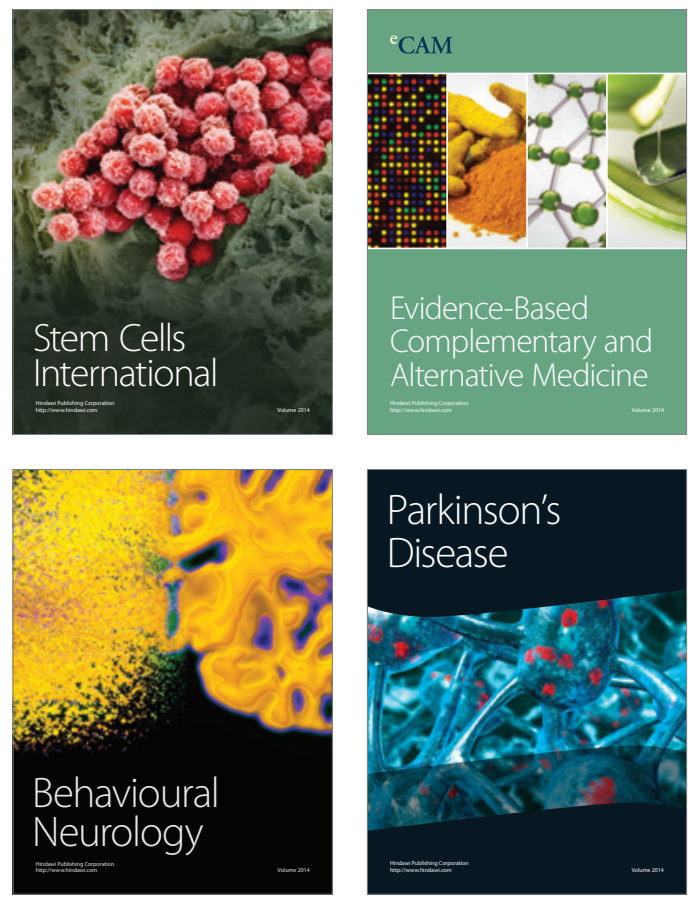
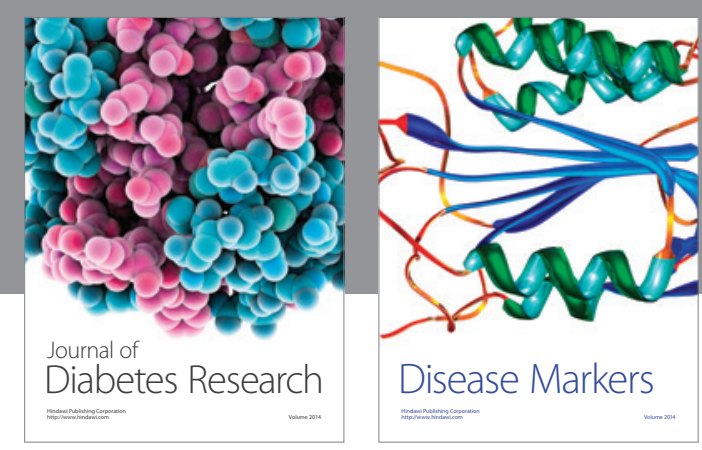

Disease Markers
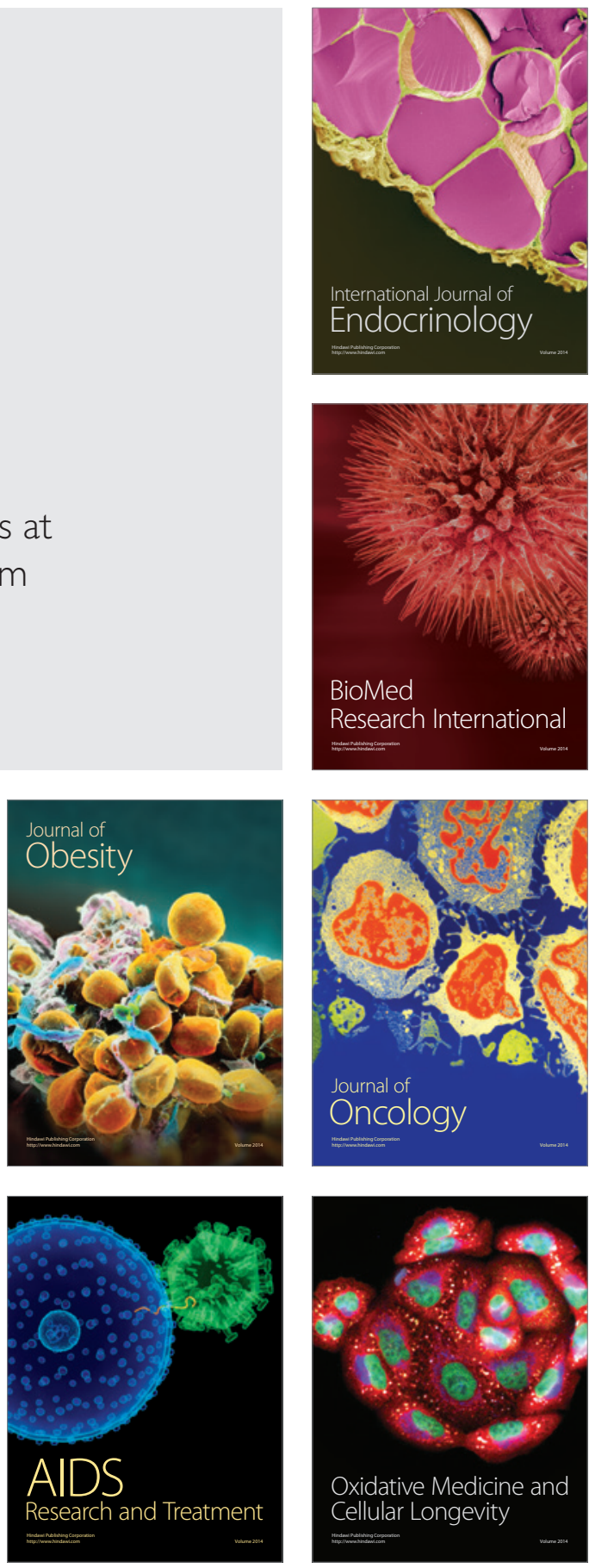